\title{
Learning Styles and Motivations for Practicing English as a Foreign Language: A Case Study of Role-play in Two Ecuadorian Universities
}

\author{
Jhonny S. Villafuerte \\ Universidad Laica Eloy Alfaro de Manabí, Manta, Ecuador; \\ The Basque Country University, Bilbao, Spain \\ Maria A. Rojas \\ Universidad Tecnica de Machala, Machala, Ecuador \\ Sandy L. Hormaza \\ Universidad Laica Eloy Alfaro de Manabí, Manta, Ecuador; \\ Universidad Católica de Murcia, Spain \\ Lourdes A. Soledispa \\ Universidad Laica Eloy Alfaro de Manabí, Manta, Ecuador; \\ Universidad de Rioja, La Rioja, Spain
}

\begin{abstract}
This action research studies the Ecuadorian university students' learning styles and motivations to practice English as a Foreign Language through Role-play. The sample is composed of 158 students from two national universities located in the Coastal region of Ecuador. They took part of Role-play practices in the English as a Foreign Language course during 2016-2017. The instruments applied were the Social Software Survey Used with Undergraduate Students; and a questionnaire designed ad hoc, by the research team named Likert Questionnaire Learners' Motivations for Practicing English through Role-play. The results show participants' openness to cooperative learning and task-based learning. It is concluded that the learning styles that participants prefer is working in groups; situation that favours the implementation of English as a foreign language practices through role-play.
\end{abstract}

Index Terms -English language, Motivation for learning, higher education, role-play, Ecuador

\section{INTRODUCTION}

To Jacobs and McCafferty (2006) acquiring a foreign language improves professional's competences in any field of knowledge. Thus, Ecuadorian university students ought to reach a proficiency level of a foreign language, before they finish their higher education (LOES, 2011). In consequence, it is a priority to develop teaching and learning strategies to support students to reach this expected knowledge.

Literature offers abundant works about English as Foreign Language (EFL) teaching and learning process that include approaches as Task-Based Learning and Teaching (TBLT) Hyland (2007), Jackson and Back (2011) and Collaborative Learning (CL) (Johnson, Johnson, and Smith,1991; Tram, 2014). However, in the current Ecuadorian context, it is necessary to explore in deeper the contributions of those approaches to strength the feasibility of educational reforms in concern to the Extensive English Language Teaching project, from the $2^{\text {nd }}$., grade of primary education to the university level (the Republic of Ecuador, 2014).

Scholars as Zhang (2010); Jackson and Back (2011); and Perez (2015), affirm that current higher educational programs require of innovative strategies to support learners' English language acquisition process through more healthy and sociable activities. Zambrano and Valverde (2013) proposed RP as a key educational strategy for strengthening learners' English communicational skills, convinced of “Role-play offers social opportunities to learn a language" (Rojas, 2017, p. 22). Finally, RP exposes the learner to a complex balance (Tran, 2014; Lee, 2014) which includes their personality, learning styles, and motivation for learning (Cevallos, Intriago, Villafuerte, Molina and Ortega, 2017; East, 2017).

In consequence, the research questions that guide this work are the following:

a) Do learning styles of university students favor their language practice through RP?

b) Are the university students motivated to execute EFL practice using RP?

\section{LITERATURE REVIEW}




\section{Role-Play in the English Language Class}

The British Council (2004) defined the term RP as "any speaking activity when you either put yourself into somebody else's shoes into an imaginary situation". To Dana Craciun (2010, p.175) "the term 'role' comes from the 'rolled-up' script actors used to use over two thousand years ago in Ancient Greece".

Students play famous characters activating their functional language in multiple scenarios and situations. The communicational content (CC) in RP should be clear and related to participants' interests. Thus, RP's CC is a "topic focus for the session and the discrete skills that will be practiced" (Jackson and Back, 2011, p. 175). Thus, 'At the restaurant' 'Checking-in at the airport' 'Looking for lost property', etc., are all possible topics to be worked using RP. Consequently, RP offers a wide range of opportunities for a foreign language practice.

According to Mayo (2011), RP consists of a group of people who pretend to be characters who represent a wide range of situations under social and interactions dynamics and the participants can define the nature of characters under key situations (Parra, 2012).

Scholars as Zambrano and Valverde (2013) defined the term "Role-play" as a recreational activity to entertain, amuse, and get access to knowledge in a significant way to create meaningful learning. In addition, RP allows learners' to develop competences for solving problems, argumentation, ideas organization, group understanding, interpreting, and inferring. RP is also a versatile teaching technique that can take place in different contexts with the active participation of children and adults. Furthermore, it is based on the pedagogical psychodrama (Perez, 2015) which requires teacher's supervision, because RP creative dynamic could detonate emotional reactions among participants. RP also offers learners and teachers, the possibility of applying different styles of correction, but it is necessary to consider that excessive correction during a learning process could be demotivating for learners (Rojas, 2017).

Cooperative Learning in the RP dynamic

The term Cooperative Learning (CL) was defined by Johnson, Johnson, and Smith (1991), as a process in which "students work together to maximize their own and each other's learning. [...] it produces higher achievement, more positive relationships among students, and healthier psychological adjustment than do competitive method" (p. 5). Therefore, CL can foster learners to use a foreign language to communicate their ideas and feelings (Slavin, 1995) during language practices. Learning activities can be more efficient when groups of peers are small because they provide supportive environments generating in learners the willingness to use a target language (Dörnyei, 1997; Jacobs and McCafferty, 2006).

Scholars agree on five basic elements that interact in all CL practice. These elements are: "(i) positive interdependence; (ii) face-to-face interaction; (iii) individual accountability and personal responsibility; (iv) frequent use of interpersonal and social skills; and (v) group processing of current functioning" (Gillies, 2007, p. 5). In addition, they ratify that cooperative learning, under the appropriate conditions, can support learners to strengthen their communicative skills when they use a foreign language (Jacobs and McCafferty, 2006; Brecke and Jensen, 2007).

In addition, Hornby (2009) argued, the practice of a foreign language requires students feel they are productive members that contribute positively to a learners' community. In such sense, the contributions of cooperative learning have gotten beyond classroom limits and supported learners` healthy social relationships (Zhang, 2010).

Naomi Lee from the Wisconsin Centre for Education Research (WIDA) introduced in 2014 the following five key themes related to CL:

(i) Developing classroom norms for executing feedback activities and resolve conflicts; (ii) Provide language support to consider English proficiency and academic proficiency, but also [...] learners' personality, social and emotional development, (iii) Organization of students groups strategically for keeping students in a home group, (iv) Creating assignments that engage all students in meaning-making to use their creativity for problem-solving skills, (v) Collaboration as a school wide value to joint planning time for executing the activities (Lee, 2014, p. 1-2).

CL had demonstrated learners' improvement of knowledge retention (Tran, 2014); nevertheless, authors as Raja, Qureshi, and Albesher (2017) recommend teachers employ during their sessions different methods of active teaching to achieve the target language in a friendly environment.

$R P$ as a Task-Based Learning and Teaching resource

Foreign language teaching and learning process require teachers to become facilitators, spectators, and even participants (Rojas, Villafuerte, Soto, 2017). The Task-Based Language Teaching (TBLT) is a relevant resource that influences positively on the communicative language teaching process. Scholars as Hyland (2007) argued that teaching practices at university courses should be analyzed from the ethnographic and critical approaches, contrastive rhetoric, social constructionism, and discourse analysis. Therefore, TBLT applied during ESP classes at the university can help learners to be the closer as possible to the future professional environments. TBLT also develops in English as foreign language learners, communicational strategies to become a more effective communicator. Furthermore, TBLT can support students to reduce their reluctant attitudes for speaking the target language (Rojas, 2017).

Nation and Newton (2009, p. 112) identified the following five possible causes of learners' reluctance to speak EFL “inadequate vocabulary, limited control of grammar, lack of fluency, learners' shyness, and lack of encouragement". In this regard, Jackson and Back (2011, p.3) argued that RP can support the "educator's ability to create a safe and motivating learning environment, to provide learners with constructive and goal-directed feedback; and to stimulate learners to reflect on their processes of communication". 
In Ecuador, according to Guanoquiza (2013) learners need to be part of stimulating and friendly environments to improve their participation and creativity in the usage of a foreign language. He also remarked that learning environments can be built through collaborative learning. In addition, teachers should let students make decisions about the organization of a RP. Such action promotes learners' autonomy (Cevallos, et al., 2017).

According to East (2017, p 416) "teachers frequently strive to differentiate a task from communicative activities that have predominated in weak Communicative Language Teaching (CLT) classroom and a Presentation-PracticeProduction model (PPP model)" Thus, RP classes set under TBLT approach, have the power to encourage learners to participate in language practices to increase authentic communicational tasks and motivate them to dedicate more time to study ESL.

Among the previous studies related to this work appears the work conducted by Guanoquiza (2013) who considered 419 English language learners' RP evaluations in Chile. Guanoquiza categorized learners' attitudes according to the factors of learners' motivation, class participation, and group creativity. His work contributed to the group of learners' oral production improvement, stimulation, and motivation for learning the foreign language in more friendly and enjoyable ways.

Tran, et al. (2014) conducted an 8-week study to assess the influence of collaborative learning on 110 primary education students' knowledge retention. Tran found that participants who participated in the RP practices (intervention group) obtained significantly higher scores on the post-test scores than the other learners (control group).

The study conducted by Shangeetha Rajah Kumaran (2017) found RP helped to encourage Malaysian secondary school students to speak English. The findings revealed that learners enjoy participating in RP.

A study conducted by East (2017) discusses TBLT in educational settings. He concluded that TBLT remains to be a challenging attempt despite the considerable theoretical and empirical support that has been developed by several authors. TBLT provides the class with an adequate environment to practice the communicational skills using a foreign language.

\section{METHODOLOGY}

This research applied the quantitative approach to determine students' learning styles and motivations in RP practice for EFL in two Ecuadorian universities. In addition, the educational intervention consisted of EFL practice that included Collaborative learning (CL) and Task-Based Learning and Teaching (TBLT) approaches. This research was developed in two national universities in the Coastal region of Ecuador during the period 2016-2017.

The sample.

It is composed of 158 students (108 female and 50 male) in ages between 21 to 42 years. The criteria of selection were (i) to be a student officially registered in any of the universities that participated, (ii) to attend classes regularly during the period of execution of the research, and (iii) availability to participate in this research.

TABLE 1

PARTICIPANTS

\begin{tabular}{lllll}
\hline Students distribution & Male & Female & Total of participants per classroom & Total of participants \\
\hline 6th Semester & 7 & 11 & 18 & \\
8th Semester & 8 & 14 & 22 & 74 \\
9th Semester & 13 & 22 & 35 & \\
\hline 4th Semester & 11 & 19 & 30 & 83 \\
5th Semester & 7 & 23 & 30 & 158 \\
7th Semester & 4 & 19 & 23 & \\
\hline Total N. & 50 & 108 & &
\end{tabular}

\section{Instruments:}

The instruments used were the following:

a. The Social Software Survey Used with Undergraduate Students by Anderson, Poellhuber, and Ross (2009). This instrument is currently distributed for Athabasca University. For this study, 13 items were selected and adjusted to the Ecuadorian context. This instrument was tested with SPSS V 24.00, obtaining a Cronbach Alpha index = 0.84; in accordance with the International Social Research Standards.

b. The Likert questionnaire titled Learners' Motivation to practice English using RP. This instrument was designed ad hoc, by the research team. It consists of 30 items that categorize learners' motivations in 3 groups: (1) participants' intrinsic motivation; (2) participants' extrinsic motivation and, (3) learners' perceptions about their English language acquisition progress. The reliability and feasibility_test_applied with SPSS V 24.00 obtained a Cronbach Alpha index = 0.82, in accordance with International Social Research Standards.

Procedure and Ethic rules:

The participants signed the Informed Consent Letter and they had 7 weeks to indicate a change of decision to participate in the process. The data is guarded by the research team and the identity of the participants is kept in anonymity. The stages of this study were the following:

Stage 1.- First Collection of data. 
At the beginning of the research was applied the Likert questionnaires.

Social Software Survey Used with Undergraduate Students of Anderson, Poellhuber, and Ross (2009) and the two first part of the Likert questionnaire Learners' Motivation to practice English using RP (intrinsic and extrinsic motivations).

Stage 2.- Educational intervention using RP activities.

The RPs were executed during a semester.

The participants were encouraged to participate in every step of the RP activities from planning to evaluation. Stage 3.- Second Collection of data.

The second collection of data used the third part of the Likert questionnaire Learners' Motivation to practice English using RP (learners' perceptions about their language acquisition progress). This questionnaire was applied after the RP session.

\section{RESULTS}

Question 1: What are the learning preferences to practice English as a foreign language?

TABLE 2

PARTICIPANTS' LEARNING STYLES PREFERENCE

\begin{tabular}{|c|c|c|c|c|c|c|}
\hline \multirow{2}{*}{ Items } & \multicolumn{3}{|l|}{ U1 } & \multicolumn{3}{|l|}{$\mathrm{U} 2$} \\
\hline & Not at all & Some & Mainly & Not at all & Some & Mainly \\
\hline $\begin{array}{l}\text { Q1. Teacher can Help most working with students in } \\
\text { groups }\end{array}$ & 12 & 40 & 23 & 20 & 38 & 25 \\
\hline Q2. Working in group leads to poor results & 36 & 30 & 9 & 40 & 23 & 20 \\
\hline Q3. I prefer work by myself so I can go fast as I like & 37 & 25 & 13 & 43 & 20 & 20 \\
\hline $\begin{array}{l}\text { Q4. It is helpful to put together everyone's ideas when } \\
\text { making a decision. }\end{array}$ & 7 & 44 & 24 & 25 & 40 & 18 \\
\hline Q5. Work in group scares me. & 37 & 28 & 10 & 41 & 32 & 10 \\
\hline Q6. I do not like working by myself. & 65 & 10 & 0 & 53 & 18 & 12 \\
\hline $\begin{array}{l}\text { Q7. In a group discussion, we never get on to important } \\
\text { things. }\end{array}$ & 63 & 11 & 1 & 53 & 19 & 11 \\
\hline $\begin{array}{l}\text { Q8. I like to be able to use the ideas of other people as } \\
\text { well as my own. }\end{array}$ & 15 & 47 & 13 & 30 & 41 & 12 \\
\hline $\begin{array}{l}\text { Q9. If I work by myself most of the time, I become lonely } \\
\text { and unhappy. }\end{array}$ & 6 & 10 & 59 & 12 & 15 & 56 \\
\hline Q10. We get the work done faster if we all work together. & 21 & 12 & 42 & 6 & 22 & $\underline{55}$ \\
\hline Q11. I do better quality work by myself & 12 & 23 & 40 & 5 & 34 & $\overline{\mathbf{4 4}}$ \\
\hline Q12. I like to help people do well in a group & 15 & 19 & 41 & 11 & 28 & $\underline{\overline{44}}$ \\
\hline Q13. Other students like to help me learn & 13 & 39 & 23 & 8 & 42 & $\overline{33}$ \\
\hline
\end{tabular}

U=University; Not at all= Disagree; Some = Neither agree nor Disagree; Mainly= Agree

Instrument applied: Social Software Survey Used with Undergraduate Students by Anderson, Poellhuber and Ross (2009).

The answers given to the participants from U1 and U2 agree on the following points:

(1) Participants` the most preferred learning styles are:

Q9. If I work by myself most of the time, I become lonely and unhappy. U1 has 56 answers and U2 59 answers.

Q10. We get the work done faster if we all work together.

U1 has 43 answers and U2 55 answers

Q11. I do better quality work by myself. U1 has 40 answers and U2 44 answers.

Q12. I like to help people do well in a group.

U2 has 41 answers and U2 44 answers.

(2) Participants' the less preferred learning styles are:

Q6. I do not like working by myself.

U1 has 65 answers and U2 53 answers

Q7. In a group discussion, we never get on to important things.

U1 has 63 answers and U2 53 answers.

Question 2: What are the participants' motivations to practice English language using role play? 
TABLE 3

PARTICIPANTS’ INTRINSIC MOTIVATION TO PRACTICE ENGLISH LANGUAGE USING ROLE-PLAY

\begin{tabular}{|c|c|c|c|c|c|c|}
\hline Items & Province & V.A. & A. & M. & D. & V.D \\
\hline \multirow{2}{*}{ 1.1. I enjoy playing the Role-play in English } & U1 & 31 & 27 & 10 & 5 & 2 \\
\hline & U2 & 35 & 22 & 12 & 8 & 6 \\
\hline \multirow{2}{*}{ 1.2. I find too difficult to execute the Role-play } & U1 & 38 & 14 & 8 & 10 & 5 \\
\hline & $\mathrm{U} 2$ & 45 & 13 & 10 & 5 & 10 \\
\hline \multirow{2}{*}{$\begin{array}{l}\text { 1.3. I am open to use Role-play during the English class } \\
\text { practices }\end{array}$} & U1 & 45 & 18 & 8 & 4 & 0 \\
\hline & U2 & 60 & 15 & 4 & 4 & 0 \\
\hline \multirow{2}{*}{$\begin{array}{l}\text { 1.4. I like to get additional information about the characters } \\
\text { used on the Role-play. }\end{array}$} & U1 & 17 & 33 & 10 & 13 & 2 \\
\hline & U2 & 12 & 35 & 15 & 14 & 7 \\
\hline \multirow{2}{*}{ 1.5. I feel shy. I do not like work in Role-play } & U1 & 34 & 21 & 10 & 5 & 5 \\
\hline & U2 & 44 & 21 & 8 & 5 & 5 \\
\hline \multirow{2}{*}{$\begin{array}{l}\text { 1.6. I think Role-play help me to improve my English } \\
\text { pronunciation. }\end{array}$} & U1 & 33 & 22 & 8 & 3 & 9 \\
\hline & U2 & 43 & 20 & 8 & 6 & 6 \\
\hline \multirow{2}{*}{$\begin{array}{l}\text { 1.7. I am emotionally involved (anger and happiness) with } \\
\text { the Role-play results. }\end{array}$} & U1 & 34 & 15 & 16 & 6 & 4 \\
\hline & U2 & 16 & 41 & 10 & 12 & 4 \\
\hline \multirow{2}{*}{$\begin{array}{l}\text { 1.8. I feel comfortable when people see me doing Role-play } \\
\text { in English }\end{array}$} & U1 & 39 & 16 & 8 & 8 & 4 \\
\hline & U2 & 26 & 33 & 21 & 1 & 2 \\
\hline \multirow{2}{*}{$\begin{array}{l}\text { 1.9. I do prefer to do other kind of activities than Role-play } \\
\text { to learn English }\end{array}$} & U1 & 6 & 11 & 43 & 15 & 0 \\
\hline & U2 & 0 & 25 & 43 & 16 & 1 \\
\hline \multirow{2}{*}{ 1.10. I feel proud of my interpretation on the Role-play. } & U1 & 21 & 22 & 15 & 13 & 4 \\
\hline & U2 & 31 & 22 & 15 & 13 & 4 \\
\hline
\end{tabular}

Note: V.A. = Very agree; A. = Agree; M. = Moderate; D. = Disagree; V.D. = Very disagree

Instrument applied: Questionnaire Learners' Motivations for Practicing English through Role-play. Part 1

(3) The more frequently positive answers were:

1.1. I enjoy playing the Role-play in English. U1 reported 31 and U2 35 positive answers.

1.3. I am open to use Role-play during the English class practice. U1 reported 45 and U2 60 positive answers.

1.6. I am able to spend extra time to improve my interpretation in the Role-play. U1 reports 33 and U2 reported 43 answers.

(4) The more frequently negative answers are:

1.2. I find too difficult to execute the Role-play. U1 reported 38 and U2 45 positive answers.

1.5. I feel shy. I do not like Role-play. U1 reported 34 and U2 44 answers.

TABLE 4

PARTICIPANTS’ EXTRINSIC MOTIVATION TO PRACTICE ENGLISH LANGUAGE USING ROLE-PLAY

\begin{tabular}{|c|c|c|c|c|c|c|}
\hline Items & Provinces & V.A. & A. & M. & D. & V.D. \\
\hline \multirow{2}{*}{ 2.1. Role-play helps me in the team work } & U1 & 45 & 12 & 9 & 6 & 3 \\
\hline & U2 & 46 & 23 & 12 & 0 & 2 \\
\hline \multirow{2}{*}{$\begin{array}{l}\text { 2.2. Accessories used in the Role-play motivate me to } \\
\text { do the practices }\end{array}$} & U1 & 20 & 10 & 15 & 14 & 16 \\
\hline & U2 & 20 & 14 & 17 & 20 & 12 \\
\hline \multirow{2}{*}{ 2.3. Role-play demands of me too much energy. } & U1 & 15 & 17 & 19 & 15 & 9 \\
\hline & U2 & 30 & 16 & 13 & 12 & 12 \\
\hline \multirow{2}{*}{ 2.4. My peers like to be part of Role-play, so I. } & U1 & 12 & 19 & 29 & 15 & 0 \\
\hline & $\mathrm{U} 2$ & 12 & 10 & 22 & 29 & 10 \\
\hline \multirow{2}{*}{ 2.5. People like to see our Role-play in English. } & U1 & 26 & 32 & 12 & 4 & 1 \\
\hline & U2 & 43 & 22 & 13 & 4 & 1 \\
\hline \multirow{2}{*}{$\begin{array}{l}\text { 2.6. My peers ask me to continue working on the Role- } \\
\text { play after class }\end{array}$} & U1 & 26 & 15 & 12 & 10 & 12 \\
\hline & $\mathrm{U} 2$ & 43 & 19 & 9 & 10 & 2 \\
\hline \multirow{2}{*}{ 2.7. My girl/boyfriend enjoys the Role-play I do. } & U1 & 32 & 22 & 10 & 6 & 5 \\
\hline & $\mathrm{U} 2$ & 33 & 21 & 16 & 6 & 7 \\
\hline \multirow{2}{*}{$\begin{array}{l}\text { 2.8. Teacher is very happy with our work in the Role- } \\
\text { play. }\end{array}$} & U1 & 22 & 21 & 20 & 5 & 7 \\
\hline & U2 & 25 & 13 & 23 & 12 & 10 \\
\hline \multirow{2}{*}{ 2.9. My peers prefer do Role-play in small groups } & U1 & 3 & 2 & 5 & 32 & 33 \\
\hline & U2 & 2 & 2 & 14 & 36 & 29 \\
\hline \multirow{2}{*}{$\begin{array}{l}\text { 2.10. Teacher says Role-play helps me to improve my } \\
\text { pronunciation in English. }\end{array}$} & U1 & 33 & 22 & 10 & 5 & 5 \\
\hline & U2 & 45 & 17 & 10 & 6 & 5 \\
\hline
\end{tabular}

Note: V.A. = Very agree; A. = Agree; M. = Moderate; D. = Disagree; V.D. = Very disagree

Instrument applied: Questionnaire Learners’ Motivations for Practicing English through Role-play. Part 2

(5) The most frequently participants' extrinsic motivations to practice English language using Role-play are:

2.1. Role-play helps me in the team work. U1 reported 45 answers and El Oro reported 46 answers.

2.4. My peers like to be part of Role-play, so I. U1 reported 26 answers and U2 reported 43 answers.

2.6. My peers ask me to continue working on the Role-play after class. U1 reported 26 answers and U2 reported

43.

2.7. My girl/boyfriend enjoys the Role-play. U1 reported 32 answers and U2 reported 33.

2.10. Teacher says Role-play helps to improve pronunciation in English. U1 reported 33 answers and U2 reported 45 answers. 
TABLE 5

PARTICIPANTS' MOTIVATION FOR LEARNING ENGLISH THROUGH ROLE-PLAY

\begin{tabular}{|c|c|c|c|c|c|c|}
\hline Items & Provinces & V.A. & A. & M. & D. & V.D. \\
\hline \multirow{2}{*}{$\begin{array}{l}\text { 3.1. I improve my English speaking skills } \\
\text { when I do Role-play }\end{array}$} & U1 & 33 & 12 & 22 & 5 & 3 \\
\hline & $\mathrm{U} 2$ & 35 & 13 & 25 & 5 & 5 \\
\hline \multirow{2}{*}{$\begin{array}{l}\text { 3.2. I learn new vocabulary in English when I } \\
\text { take part of Role- play. }\end{array}$} & U1 & 26 & 21 & 13 & 8 & 7 \\
\hline & $\mathrm{U} 2$ & 30 & 23 & 10 & 10 & 10 \\
\hline \multirow{2}{*}{$\begin{array}{l}\text { 3.3. I try to use correct English grammar } \\
\text { when I do Role-play. }\end{array}$} & U1 & 33 & 26 & 10 & 3 & 3 \\
\hline & $\mathrm{U} 2$ & 43 & 20 & 10 & 5 & 5 \\
\hline \multirow{2}{*}{$\begin{array}{l}\text { 3.4. Role-playing encourages me to speak in } \\
\text { English more often }\end{array}$} & U1 & 32 & 23 & 12 & 4 & 4 \\
\hline & $\mathrm{U} 2$ & 45 & 32 & 6 & 0 & 0 \\
\hline \multirow{2}{*}{$\begin{array}{l}\text { 3.5. I try to use correct grammar structures } \\
\text { when I do Role-play. }\end{array}$} & U1 & 35 & 13 & 12 & 8 & 7 \\
\hline & $\mathrm{U} 2$ & 20 & 21 & 22 & 10 & 10 \\
\hline \multirow{2}{*}{$\begin{array}{l}\text { 3.6. I can assess progress speaking when I do } \\
\text { Role-play. }\end{array}$} & U1 & 29 & 21 & 13 & 10 & 2 \\
\hline & $\mathrm{U} 2$ & 30 & 11 & 31 & 9 & 4 \\
\hline \multirow{2}{*}{$\begin{array}{l}\text { 3.7. I improve my vocalization when I work } \\
\text { on the Role-play }\end{array}$} & U1 & 31 & 10 & 21 & 9 & 4 \\
\hline & $\mathrm{U} 2$ & 32 & 11 & 13 & 15 & 12 \\
\hline \multirow{2}{*}{$\begin{array}{l}\text { 3.8. I pay attention and follow the Role-play } \\
\text { instructions because is important. }\end{array}$} & U1 & 22 & 23 & 14 & 11 & 5 \\
\hline & $\mathrm{U} 2$ & 32 & 21 & 14 & 11 & 5 \\
\hline \multirow{2}{*}{$\begin{array}{l}\text { 3.9. I improve my self-confidence when I } \\
\text { perform the Role-play }\end{array}$} & U1 & 34 & 16 & 17 & 5 & 3 \\
\hline & $\mathrm{U} 2$ & 54 & 13 & 7 & 4 & 5 \\
\hline 3.10. I am interest to practice English using & U1 & 15 & 32 & 11 & 14 & 3 \\
\hline Role-play. & $\mathrm{U} 2$ & 22 & 31 & 17 & 12 & 1 \\
\hline
\end{tabular}

Note: V.A. = Very agree; A. = Agree; M. = Moderate; D. = Disagree; V.D. = Very disagree.

Instrument applied: Questionnaire Learners' Motivations for Practicing English through Role-play. Part 3

(6) Participants` perceptions about Role-play contributions to their English language acquisition process.

3.1. I improve my English speaking skills when I do Role-play. U1 reported 33 answers and U2 reported 35 answers.

3.3. I try to use correct English grammar when I do Role-play. U1 reported

33 answers and $\mathrm{U} 2$ reported 43 answers.

3.4. Role-playing encourages me to speak in English more often. U1 reported 32 answers and U2 reported 45 answers.

3.9. I improve my self-confidence when I perform the Role-play. U1 reported 34 answers and U2 reported 54 answers.

\section{DISCUSSION}

Based on this research results, the authors agree with Scholars as Zambrano and Valverde (2013) that RP develop learners' competences for problem-solving, argumentation, organization of ideas, group understanding, interpreting, and inferring; however, Ecuadorian teachers refuse to use RP in the foreign language classes, because it requires enormous amounts of energy and is a reason for the disorder in the classroom (British Council, 2011). It looks that the most important aspect is the control of the class discipline instead of promoting the self-assessment and the use of the language under creative activities.

Mayo (2011) and Parra (2012) agree about the fact that RP offers to learners a wide range of situations for practice a language under social and interactions dynamics. RP also offers the ideal scenario to apply the Communicational Learning and Task-Based Learning and Teaching approaches.

This research results show that RPs enable learners to be involved in an environment free of rivalry. Furthermore, their capabilities for creativity are active when they look for a way to contribute in the diverse steps of RP production.

Authors such as Guanoquiza (2013) and Rojas (2017) agree that learners need to be exposed to friendly, but stimulating environments, to improve their current EFL communicational competences. They remark the possibility that such environments can be built through collaborative learning approach. In addition, RP also has the power to simulate in the classroom the competitive work future environments; in consequence, its contribution to the future professional is relevant.

a) Do learning styles preferred for the university students favor their language practice through RP?

Participants prefer to have group activities for developing language practice. They also prefer to do language practice with activities that allow them to detect their error when using the target language. The items: "Q4. It is helpful to put together everyone's ideas when making a decision; Q9. If I work by myself most of the time, I become lonely and unhappy; Q10. We get the work done faster if we all work together; Q12. I like to help people do well in a group".

The authors consider that RP is a learning activity that provides students a wide range of opportunities to identify their English mistakes in any of the stages of the RP preparation (planning, rehearsal, and presentation, etc.). Additionally, it is necessary to have a very clear purpose of the language practice to establish coherent evaluation procedures.

b) Are the university students motivated to execute EFL practice using RP?

b.1. Participants' intrinsic motivations practice English Language using RP. 
About the participants' extrinsic motivations, it is observed positive and negative positions toward RP. The positive points concern "1.1. I enjoy playing the RP in English; 1.3. I am open to using RP during the English class practice; 1.6. I am able to spend extra time to improve my interpretation in the RP". The analysis showed participants are open to practicing English language using RP under the condition they be inside the classroom. They are also able to dedicate time and work to improve their achievement to do a good work when they do ESL practices using RP.

However, participants also find RP is a difficult ESL practice. In addition, elements of their personality as shame and self-estimation are always present.

b.2. Participants' extrinsic motivations practice English Language using $R P$.

Participants' extrinsic motivations are centered on the social and affective relationships, in special with the partners, boy-girlfriend and teacher. "2.1. RP help me in the teamwork; my peers like to be part of RP, so I; 2.6. My peers ask me to continue working on the RP after class; 2.7. My girl/boyfriend enjoys the RP; 2.10. Teacher says RP helps to improve pronunciation"

The Cooperative learning acquires a relevant importance in the execution of RP because it requires every learners' cooperation to the successful execution.

b.3. Participants' Motivation for English language learning.

The participants have a diverse range of perceptions about RP contributions. "3.1. I improve my English speaking skills when I do RP; 3.3. I try to use correct English grammar when I do RP; 3.4. Role-playing encourages me to speak English more often; 3.9. I improve my self-confidence when I perform the RP”.

Task-Based Learning and Teaching support efficiently the execution of a RP in the diverse stages from planning to evaluation. The results of this work confirm the position of Nation and Newton (2009) and Jackson and Back (2011) concerning RP as a supporting activity to implement constructive feedback.

The results ratify the position of Jacobs, et al (2006), Rojas, et al (2017) and Raja, et al (2017) who considers that students learn English more successfully when they are exposed to natural and contextualized environments. In consequence, RP encourages students to use the target language. For this purpose, because of the effective results, it is necessary to encourage teachers to apply RP more frequently in the university classroom regardless of the time constraints, little availability of materials, and considerable energy demand.

\section{CONCLUSION}

It is concluded that, Role-play is learning and teaching strategy that positively supports the English as a Foreign Language acquisition process in the Ecuadorian university context. The participants showed a preference for group learning activities. Therefore, Role-play has widely potentialities to be used in English classes. In addition, when RP is supported with the CL approach, it can strengthen students' team work more efficiently. Participants found RP as a difficult language practice, however; both intrinsic and extrinsic learners' motivations revealed that participants were available to practice EFL using RL as a Task-Based Learning activity.

\section{REFERENCES}

[1] Anderson, T., B. Poellhuber \& M. Ross. (2009). Social Software in Athabasca's Undergraduate Studies. Athabasca University Library. https://auspace.athabascau.ca/handle/2149/2771 (accessed 15/01/2018).

[2] British Council, BC. (2004). Role-play. [Teaching English Blog]. https://www.teachingenglish.org.uk/article/role-play (accessed 15/10/2017).

[3] Cevallos, J., E. Intriago, J. Villafuerte, G. Molina \& L. Ortega. (2017). Motivation and Autonomy in Learning English as Foreign Language: A Case Study of Ecuadorian College Students. Journal of English Language Teaching. 10.2, 100-113. http://www.ccsenet.org/journal/index.php/elt/article/view/65784 (accessed 08/01/2018).

[4] Clarene, C. A. (2011). Nociones de Cibercultura y Periodismo. San Carlos de Bariloche, Argentina

[5] Craciun, D. (2010). Role - playing as a creative method in science education. Journal of Science and Arts. 10.1, 175-182. (accessed 09/10/2017).

[6] Dörnyei, Z. (1997). Psychological processes in cooperative language learning: Group dynamics and motivation. Modern Language Journal, 81.1, 482-493.

[7] East, M. (2017). Research into practice: The task-based approach to instructed SL acquisition. Language Teaching, 50.3, 412424. https://doi.org/10.1017/S026144481700009X (accessed 15/08/2017).

[8] Gillies, R. M. (2007). Cooperative Learning. Integrating Theory and Practice. Los Angeles: Sage Publications.

[9] Guanoquiza, C. (2013). The role play as a teaching - Learning strategy for enhancing English levels in high school students in a Chilean context. [Carlos Guanaquisa Becario Ecuatoriano 2011]. https://www.teachingenglish.org.uk/article/role-play (accessed 15/10/2017).

[10] Hornby, G. (2009). The effectiveness of cooperative learning with trainee teachers. Journal of Education for Teaching: International Research and Pedagogy, 35.2, 161-168.

[11] Hyland, K. (2007). English for specific purposes. In Cummins, J. \& C. Davison, (Eds.) International handbook of English language teaching. DOI 10.1007/978-0-387-46301-8 (accessed 12/10/2017).

[12] Jackson, V. \& A. Back (2011). Teaching Communication Skills Using Role-Play: An Experience-Based Guide for Educators. Journal of Palliative Medicine, 14. 6, 775-780. doi:10.1089/jpm.2010.0493 (accessed 11/10/2017). 
[13] Jacobs, G. M. \& S.G. McCafferty. (2006). Connections between cooperative learning and second language learning and teaching, in: McCafferty, S.G., G. M. Jacobs \& A. C. DaSilva Iddings (Eds) Cooperative Learning and Second Language Teaching. Cambridge, 18-29: Cambridge University Press.

[14] Johnson, D., R. Johnson \& K. Smith. (1991). Cooperative Learnim Increasing College Faculty Instructional Product Mry. ASHE-ENC Higher Education Report No. 4. Washington, D.C.: The George Washington University, School of Education, and Human Development. In http://files.eric.ed.gov/fulltext/ED343465.pdf (accessed 16/10/2017).

[15] Johnson, D. W. \& R.T. Johnson (2009). An educational psychology success story: Social interdependence theory and cooperative learning. Educational Researcher, 38.5, 365-379. Washington, DC: American Educational Research Association (AERA).

[16] Kumaran, S. (2017). Benefits and shortcomings of role-play as a speaking activity in English language classrooms. The English Teacher, 39.1, 72-93. https://journals.melta.org.my/index.php/tet/article/view/273/170 (accessed 15/10/2017).

[17] Lee, C. D. \& P. Smagorinsky (Eds.). (2000). Vygotskian perspectives on literacy research: Constructing meaning through collaborative inquiry. Cambridge, UK: Cambridge University Press.

[18] Lee, N. (2014). Collaborative Learning for English Language Learners. [Wisconsin Center for Education Research]. hppt:/research_Briefs_WIDA_Rsrch_Brief_CollaborativelearningforELLs (accessed 10/09/2017).

[19] NamazianDost, I., G. Bohloulzadeh \& A. Pazhakh. (2017). The Effect of Task-Based Language Teaching on Motivation and Grammatical Achievement of EFL Junior High School Students. Advances in Language and Literary Studies. 8. 2 , $243-259$. Doi:10.7575/aiac.alls.v.8n.2p.243.

[20] Nation, I. \& J. Newton. (2009). Teaching ESL / EFL Listening and Speaking. New York: Routledge, Taylor \& Francis. http://perpus.stkipkusumanegara.ac.id/file_digital/Buku\%20Digital\%2056.pdf (accessed 29/12/2017).

[21] Parra, D. M. (2012). Tesis de Máster en Profesorado de Educación Secundaria. La Potencialidad Didáctica de los juegos de rol para la enseñanza aprendizaje de las Ciencias Sociales. España.

[22] Perez, D. M. (2015). El role-playing de la escuela a la vida. Valladolid: Universidad de Valladolid.

[23] Raja, M., A. Quressi \& K. Albesher. (2017). Application of Cooperative Learning Strategies (CLS) for Students' Focused Teaching (SFT) in EFL Class: An Experimental Study in the Summer Remedial Course for Adult Learners. Journal of Language Teaching and Research. 8.2, 237-252. Doi http://dx.doi.org/10.17507/j1tr.0802.05 (accessed 25/09/2017).

[24] Republica del Ecuador. (2014). Acuerdo No. 0052-14. Ministerio de Educación. https://educacion.gob.ec/wpcontent/uploads/downloads/2014/03/ACUERDO-052-14.pdf. (accessed 14/10/2017).

[25] Rojas Encalada, M. A. (2017). Al Efl Students' Insights About The Use Of Role-play In Two English For Specific Purpose (esp) Courses To Develop Speaking Skills In The Hotel And Tourism Management Career Of a Public University In Ecuador (Master's thesis, Espol).

[26] Slavin, R. E. (1995). Cooperative learning theory, research, and practice. Massachusetts: Simon \& Schuster, Inc.

[27] Spratt, M., G. Humphreys \& V. Chan. (2002). Autonomy and motivation: Which comes First. Journal Language Teaching Research, 6.1, 245-266. https://doi.org/10.1191/13621688021r106oa (accessed 14/10/2017).

[28] Tran, V. D. (2014). The Effects of Cooperative Learning on the Academic Achievement and Knowledge Retention. International Journal of Higher Education. 3.1, 131-140. doi:10.5430/ijhe.v3n2p131 (accessed 11/12/2017).

[29] Zambrano, E. G., \& B. A.Valverde. (2013). Consolidación de Destrezas con criterio de desempeño en primero de EGB. Cuenca: Universidad de Cuenca.

[30] Zhang, Y. (2010). Cooperative Language Learning and Foreign Language Learning and Teaching. Journal of Language Teaching and Research, 1.1, 81-83. http://citeseerx.ist.psu.edu/viewdoc/download?doi=10.1.1.665.8428\&rep=rep1\&type=pdf (accessed 14/10/2017).

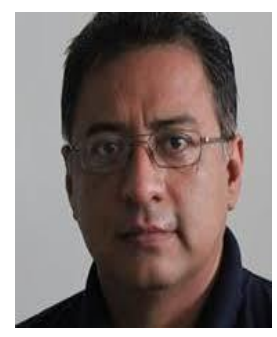

Jhonny S. Villafuerte. Ecuadorian researcher graduated from the Master's Program in Psycho Didactics from the University of the Basque Country, Spain; and from the Master's Program in Educational Research at Universidad Nacional de Loja, Ecuador. Other studies about education and local development were conducted in Chile, Brazil, USA, Germany, Belgium, Spain, England, Israel, Uganda, Mali, Russia, India and China. He is professor at the Laica Eloy Alfaro de Manabí University. His research lines are: Human and Sustainable Development; Educational Technology and language; Inclusive Entrepreneurship. His recently works are: La investigación cualitativa rutas para la puesta en práctica (book); Learners' Attitudes toward Foreign Language Practice on Social Network Sites (article); and Motivation and Autonomy in Learning English as Foreign Language (article).

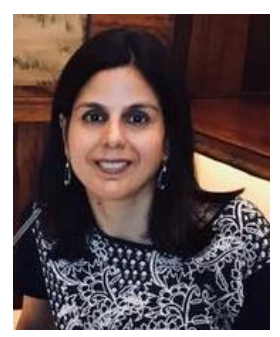

Maria A. Rojas was born in Guayaquil, Ecuador. In 2017 she earned a Master's Degree in Teaching English as a Foreign Language at Escuela Superior Politeécnica del Litoral (ESPOL) in Ecuador. Her major field of study focuses on English Language Teaching (ELT). She has been working as an ESP professor at Universidad Tecnica de Machala (UTMACH) in Machala, Ecuador since the year 2014. Prof. Rojas is a member of a Research Group called ELT Innovator at UTMACH. Her recently publications are: Collaborative Work and Technological Means for improving Learners' English Language Writing Production (The Turkish Online Journal of Educational Technology, 2017), Performance-Based Tasks as a Mean to Assess the Speaking of Learners of English as a Foreign Language (The Turkish Online Journal of Educational Technology, 2017), and English Language Teaching Approaches: A comparison of the Grammar-Translation, Audiolingual, Communicative, and Natural Approaches (Theory and Practice in Language Studies, 2017). 


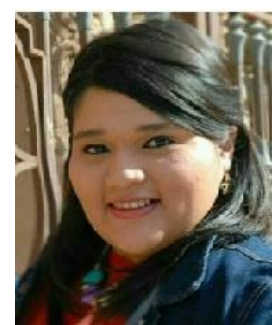

Sandy L. Hormaza graduated from the Master's Program in Marketing and Communication from the Catholic University San Antonio, Spain. Other studies about Tourism development and local development were conducted in Belgium. She is professor at the Laica Eloy Alfaro de Manabí University. Her research lines are: Educational and language, Communication and Tourism development.

Her recently works are: -Máster oficial en Marketing y Comunicación en la de Murcia (UCAM). "Viaje a Bruselas y visita de las instalaciones Europeas. At the present time she continues conducting CLIL research projects for future publications.

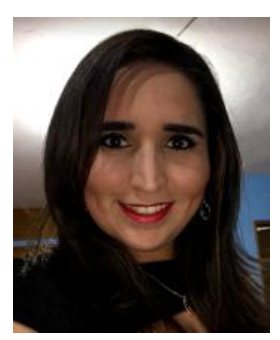

Lourdes A. Soledispa Mendieta was born in Santo Domingo de los Colorados, Ecuador. In the year 2006 she obtained a Bachelor's degree in Language with a major in English at Universidad Laica Eloy Alfaro de Manabí (ULEAM) in Manta, Ecuador. Currently she is earning a Master's Degree in Bilingual Education at Universidad Internacional de La Rioja (UNIR) in La Rioja, España. The author's major field of study focuses on Content and Language Integrated Learning (CLIL).

She worked as a school and high school Music and English teacher in different private educational institutions for 14 years. Currently, she has been working as English music teacher at Unidad Educativa Julio Pierregrosse (UEJP) in Manta, Ecuador since the year 2012. At the present time she continues conducting CLIL research projects for future publications. 